\title{
Analiza i kritički osvrt na župna pastoralna vijeća i njihove odbore u Đakovačko-osječkoj nadbiskupiji
}

\author{
Stanislav Šota*
}

\begin{abstract}
Sažetak
U duhu sinodalnosti Drugoga vatikanskog koncila, Đakovačko-osječka nadbiskupija nastoji sve članove mjesne Crkve povezati u suodgovornu cjelinu, $u$ kojoj se svaki krštenik u okvirima vlastite karizme može ostvariti kao suodgovoran sudionik u životu Crkve. Ostvarenje sinodalnog duha mjesne Crkve posebno se »mora " prepoznati u župnim strukturama, a napose u župnim pastoralnim vijećima. Zadaće župnog pastoralnog vijeća, kao savjetodavnog tijela, su: pomoć župniku u otkrivanju evangelizacijsko-pastoralno-katehetskih prioriteta i potreba na terenu; postavljanje prioritetnih zadataka u župi; otkrivanje i nastojanje oko uključivanja župljana u odbore i pododbore predviđene Sinodskim dokumentima Đakovačke i Srijemske biskupije, te Pravilnikom za župna pastoralna vijeća Đakovačko-osječke nadbiskupije. Odbori župnih pastoralnih vijeća za naviještanje, liturgiju i karitativnu djelatnost daju nužnu unutarnju strukturiranost po kojoj je moguće ostvariti ciljeve župnih pastoralnih vijeća (ŽPV). Ta vijeća i njihovi odbori trebali bi biti oblikovani na način da njihova narav, obilježja i zadaće strukturalno utjelovljuju sve pojedine evangelizacijske etape te tako budu strukturalni okvir planiranja, provedbe i vrednovanja pastoralnog djelovanja župe u cjelini.

Ključne riječi: sinodalnost, suodgovornost, strukturiranost, župno pastoralno vijeće, odbor župnog pastoralnog vijeća za naviještanje, liturgiju i karitativnu djelatnost
\end{abstract}

\section{Uvod}

Crkva, kao narod Božji, vlastiti identitet izražava i ostvaruje trostrukom službom: naviještajući Božju riječ, slaveći sakramente i služeći u ljubavi. ${ }^{1}$ Niti jedna

* Dr. Stanislav Šota, Adresa: Katolički bogoslovni fakultet Đakovo, P. Preradovića 17. 34400 Đakovo. E-pošta: stanislav.sota@os.t-com.hr

1 Usp. Drugi vatikanski koncil, Dogmatska konstitucija Lumen gentium, o Crkvi, Zagreb, 1993, 12, str. 111. 
od tih zadaća i službi ne isključuje druge dvije, nego se međusobno pretpostavljaju i nadopunjuju. ${ }^{2}$ Riječ je o eklezijalno-pastoralnoj stvarnosti utemeljenoj na osobnoj povezanosti i zajedništvu s Kristom. Kršćansko zajedništvo je ponajprije ljubavlju prožeta organska stvarnost, koja traži organizacijski pastoralno-katehetski ustrojen pristup, rad, planiranje, programiranje i njezino strukturiranje. ${ }^{3}$ Sinodalni duh ostvaren na Drugom vatikanskom koncilu ${ }^{4}$ poticaj je, nadahnuće i model ${ }^{5}$ koji omogućuje svim članovim Crkve sustavno i organizirano življenje vlastite suodgovornosti. ${ }^{6}$ Prezbiterocentrizam trebao bi ustuknuti pred pluriministerijalnošću na svim razinama. ${ }^{7} \mathrm{U}$ duhu sinodalnosti Drugoga vatikanskog koncila, Druga sinoda Đakovačke i Srijemske biskupije, danas Đakovačko-osječke nadbiskupije, nastoji sve članove mjesne Crkve povezati u suodgovornu cjelinu u kojoj se svaki krštenik u okvirima vlastite karizme može ostvariti kao suodgovoran sudionik u životu Crkve. ${ }^{8}$ Prvi dio rada ukratko prikazuje i analizira narav sinodalnosti župnog pastoralnog vijeća (ŽPV), a drugi dio prikazuje Sinodske dokumente Druge sinode Đakovačke i Srijemske biskupije, ${ }^{9}$ ujedno krajevno pravo Crkve đakovačko-osječke, posebice upute o osnivanju i potrebitoj strukturi, naravi i svrsi odbora župnoga pastoralnog vijeća za naviještanje, liturgiju, karitativnu djelatnost, izgradnju zajedništva te njihovu evangelizacijsko-pastoralno katehetsku ulogu i važnost u župama Đakovačko-osječke nadbiskupije. U trećem dijelu donosi se statistika, analiza i kritički osvrt na župna pastoralna vijeća te Pravilnikom predviđena tri odbora župnih pastoralnih vijeća: odbor za naviještanje, liturgiju i karitativnu djelatnost, njihovo osnivanje, brojnost i prisutnost, rad, djelovanje i ulogu u župnim zajednicama; dob, spol, zvanje, zanimanje u Đakovačko-osječkoj nadbiskupiji. Osnovne pastoralne smjernice i prijedlozi, koji će zasigurno pridonijeti kvalitetnomu pastoralnomu djelovanju ŽPV-a i odbora ŽPV-a za naviještanje, liturgiju i karitativnu djelatnost, sadržaj je zadnjeg dijela rada.

2 Usp. Benedikt XVI., Deus caritas est. Bog je ljubav, Zagreb, 2006, 25, str. 39-40.

3 Usp. Ivan Pavao II., Novo millennioineunte. Ulaskom u novo tisućljeće, Zagreb, 2001, 43-45, str. 56-60.; Anton Bozanić, Perspektiva župnih pastoralnih vijeća u današnjem pastoralu i apostolatu laika, u: Bogoslovska smotra, 1998, 7, 3, str. 44.

4 Usp. Nikola Vranješ, Ostvarenje sinodalnog stila pastoralnog djelovanja na župnoj razini. Djelovanje kao autentični izričaj zajedništva Crkve, u: Bogoslovska smotra, 2010, 80,4, str. 1209-1233. Đuro Hranić, Teološki temelji sinodalnosti u mjesnoj Crkvi, u: Vjesnik Đakovačke i Srijemske biskupije 1999, 127, 3, str. 153

5 Usp. Nikola Bižaca, Sinodalnost preduvjet uspjeha nove evangelizacije, u: Crkva u svijetu, 2012, 47,3 , str. 295-298.

6 Usp. Nikola Vranješ, Ostvarenje sinodalnog stila..., u: Bogoslovska smotra, 2010, 80, 4, str. 12091233.

7 Usp. Alphonse Borass, I ministri oggi: oltreildivario tra clero e laicato, u: La Rivista del clero Italiano, 2009, 90, 7-8, str. 535-548.

8 Usp. Marin Srakić (proglasio), Ti si Krist za nas i za sve ljude: Izjave i odluke Druge biskupijske sinode đakovačke i srijemske, 2008, 1, str. 20.

9 18.lipnja 2008. ponovno je uspostavljena Srijemska biskupija, a ostali dio Đakovačke i Srijemske biskupije podignut je na razinu nadbiskupije i preimenovan u Đakovačko-osječku nadbiskupiju. Nadbiskupija je ujedno i metropolija đakovačko-osječka. 


\section{1. Župno pastoralno vijeće - župna sinodalna struktura}

Sinode i sinodalni stil djelovanja omogućava svim članovim Crkve sustavno i organizirano življenje vlastite suodgovornosti. Sinodalnost se ponajprije i isključivo odnosi na povezivanje svih crkvenih subjekata u organski povezanu suodgovornu cjelinu u kojoj su točno određene i nepromjenjive bitne razlike $\mathrm{s}$ obzirom na službe i uloge, pri čemu se svaki krštenik može u okvirima vlastite karizme ostvariti kao suodgovoran sudionik u poslanju Crkve. ${ }^{10}$ Kada je riječ o mjesnoj Crkvi, tada se ponajprije misli na župu, kao temeljnu organizacijsku ustanovu zajedničkog kršćanskog života te se zbog toga ispravno ostvarenje cjelokupnog evangelizacijskog procesa nezaobilazno mora započeti od obnove župnih struktura u svjetlu ispravno shvaćene sinodalnosti. ${ }^{11}$ Sinodalnost na župnoj razini ostvaruje se kroz dva vida, kroz implicitnu i eksplicitnu sinodalnost. Dok se implicitna odnosi na svjedočenje i življenje vjere u obiteljskom, društvenom i radnom okružju u kojem župljani žive, eksplicitna se ostvaruje kroz forme suradnje na župnoj razini, pri čemu se u prvom redu misli na župna pastoralna vijeća i pripadajuće im odbore. Riječ je o sinodalnom tijelu koje je strukturirano kao ogledalo župne zajednice i čija je temeljna svrha služiti, u institucionalnom okviru, uređenoj suradnji vjernika u unapređenju pastoralne djelatnosti koja je svojstvena prezbiterima — župnicima ${ }^{12}$. Tu se u prvom redu misli na propitkivanje i analizu znakova vremena, osobito koliko se oni odražavaju na život konkretne župne zajednice te poticanje suodgovornosti svih vjernika na suradnju u djelu Crkve u konkretnoj župi. ${ }^{13}$ Vjernici imaju pravo i dužnost, prema svojemu znanju i stručnosti, župniku ukazivati i očitovati osobna promišljanja o unapređenju vjerskog života i rada (usp. 212, § 3). Župno pastoralno vijeće ne donosi odluke, nego je po svojoj naravi savjetodavno tijelo (usp. kan. 536, § 2) koje župniku iznosi primjedbe i prijedloge na evangelizacijsko-pastoralno-katehetskom području. Savjetodavno odlučivanje uvijek mora sadržavati župnikovo suglasje. ${ }^{14} \mathrm{Na}$ taj je način župno pastoralno vijeće, uz pripadajuće odbore, jedna od prvotnih struktura sinodskog duha, naravi i suodgovornosti. Riječ je o sinodalnom tijelu ${ }^{15}$ koje je strukturirano kao »ogledalo« župne zajednice, ${ }^{16}$ čija je

10 Ivan Pavao II, Christifideles laici, Dokumenti 93, Zagreb, 1990, 32-34, str. 74-80.

11 Usp. Marin Srakić (proglasio) Izjave i odluke...554, str.258.

12 Kongregacija za kler, Prezbiter, pastir $i$ vođa župne zajednice, Dokumenti 131, Zagreb, 2003, 26, str. 60 .

13 Hrvatska biskupska konferencija, Za život svijeta, Pastoralne smjernice za apostolat vjernika laika u Crkvi i društvu u Hrvatskoj, Zagreb, 2012, 108, str. 103.

14 Usp. Tomislav Đukez, Župno pastoralno vijeće u Đakovačko-osječkoj nadbiskupiji, Opći i partikularni propisi, u: Vjesnik Đakovačko-osječke nadbiskupije i Srijemske biskupije, 2016, 144, 1, str. 5.

15 Uz govor o sinodalnosti usko se veže i govor o supsidijarnosti u Crkvi, o toj temi više u: Walter Kasper, Zum Subsidiaritätsprinzip in der Kirche, u: Communio Internazionale katholische Zeitschrift, 1989, 18, 2, str. 155-162.; Stjepan Baloban, Mogućnost supsidijarnosti u crkvenom životu, u: Bogoslovska smotra, 2009, 79, 1, str. 147-163.

16 Usp. Alojzije Čondić, Župno pastoralno vijeće - ogledalo župne zajednice, u: Služba Božja, 2009, 49, 3, str. 273-290. 
temeljna svrha kroz institucionalnu suodgovornost, angažiranost i suradnju ${ }^{17} \mathrm{~s}$ vjernicima laicima, praktičnim vjernicima, biti savjetodavno tijelo koje u župi unapređuje pastoralno djelovanje zajedno sa župnikom. Kako bi se razvijao i ostvarivao duh sinodalnosti, važno je kod vjernika laika trajno uočavati i poticati razvoj različitih karizmi, ${ }^{18}$ kako bi sve karizme bile »ukomponirane « u zajednički vid naviještanja, liturgije i služenja izgrađujući kršćansko zajedništvo. Župno pastoralno vijeće, nadalje, treba voditi računa o suradnji u stvaranju pastoralnog plana župe, imajući pred očima opći plan mjesne Crkve. U tom smislu, vijeće pod predsjedanjem i vodstvom župnika sudjeluje u ostvarivanju trostruke zadaće Crkve, poduzimajući i koordinirajući razne postojeće pastoralne inicijative, i traga za novim. Zadaće ${ }^{19}$ župnog pastoralnog vijeća, kao savjetodavnog tijela su: pomoći župniku u otkrivanju evangelizacijsko-pastoralno-katehetskih prioriteta i potreba; postavljanje prioritetnih zadataka u župi; otkrivanje i nastojanje oko uključivanja župljana u odbore i pododbore; izgradnja dijaloga unutar župne zajednice, dekanata, mjesne Crkve i društvene sredine; promicanje koncilskog nauka, rad na vjerskoj i moralnoj obnovi župe.

\section{Struktura, narav i svrha odbora župnog pastoralnog vijeća}

Novonastale okolnosti i suvremeni evangelizacijsko-pastoralno-katehetski izazovi zahtijevaju da se unutar župnih pastoralnih vijeća, radi boljeg (samo) ostvarenja župnih pastoralnih vijeća, osnuju određeni odbori i pododbori kao njihova strukturalna tijela. ${ }^{20}$ Odbori vijećima daju nužnu unutarnju strukturiranost po kojoj je tek moguće ostvariti ciljeve vijeća. Riječ je o tijelima koja bi trebala biti oblikovana na način da njihova narav, obilježja i zadaće strukturalno utjelovljuju sve pojedine evangelizacijske etape ${ }^{21}$ te tako budu strukturalni okvir planiranja, provedbe i vrednovanja pastoralnog djelovanja vijeća i župe u cjelini. Tako, primjerice, prema zaključcima Druge biskupijske sinode đakovačke i srijemske, župno pastoralno vijeće treba biti strukturirano kroz četiri odbora: za naviještanje, liturgiju, karitativnu djelatnost i izgradnju zajedništva. ${ }^{22}$ Kako bi odbori župnog pastoralnog vijeća pridonijeli kvaliteti evangelizacijsko-pastoral-

17 Alojzije Čondić, Pastoralno programiranje crkvenoga rada, u: Crkva u svijetu, 2007, 42, 3, str. 431-435.

18 Usp. Richard R. Gailladetz, The Ecclesiological Foundationsof Ministry within an Ordered Communion, u: Susan K. Wood (ur.), Orderingthe Baptismal Priesthood. Theologies of Layand Ordained Ministry, Collegeville, 2003.

19 Usp. Drugi vatikanski koncil, Dekret o apostolatu laika. Apostolicam actuositatem, 26, str. 453455.; Jane Ferguson, Handbook for Parish Pastoral Councils, 2005. Mark F. Fischer, Making Parish Councils Pastoral, 2010.; Živan Bezić, Župsko pastoralno vijeće, u: Crkva u svijetu, 1980, 16, 1, str. 30-39.

20 Usp. Marin Srakić (proglasio) Izjave i odluke..., 575, str. 265.

21 Usp. Pavao VI., Evangelii nuntiandi, Zagreb, 2000, 17-24, str. 17-22.

22 Usp. Marin Srakić (proglasio), Izjave i odluke..., 575, str. 265. Pravilnik župnog pastoralnog vijeća u Đakovačko-osječkoj nadbiskupiji donosi tri odbora ŽPV-a: za naviještanje, liturgiju i karitativnu djelatnost. Usp. Marin Srakić (odobrio), Pravilnik župnog pastoralnog vijeća u Đakovačko- 
no-katehetskog rada i djelovanja, njihov ustroj, planiranje, konkretno djelovanje i vrednovanje rada mora uključivati međusobni dijalog i koordinaciju s pastoralnim vijećem i župom u cjelini. Koordinirano pastoralno djelovanje odbora stvarat ce ozračje za cjelovit duhovni rast i konkretan život u vjeri. Zatim, djelovanje odbora potrebno je uskladiti s dugoročnim, srednjoročnim i kratkoročnim pastoralnim planovima župe, dekanata i biskupije te postojećim organizacijskim i financijskim planovima. Napose redovite članove odbora treba »osvježavati« novim snagama; dakle, u odbore uključivati zainteresirane praktične vjernike kao pridružene članove. Potrebno je ujedno stvarati ozračje za aktivno uključivanje što većeg broja vjernika u pojedine odbore (posebice u angažmanu unutar pastoralno-katehetskih skupina), voditi zapisnike susreta i evidenciju pojedinih zaduženja i aktivnosti članova odbora, poticajno djelovati na sve skupine u župi, vrednovati izvješća o radu skupina u župi te na temelju istih planirati i koordinirati buduće djelovanje.

\subsection{Narav i struktura odbora župnog pastoalnog vijeća za naviještanje}

Trajna promjenjivost osobnih, obiteljskih i društvenih prilika stavlja pred Crkvu trajnu obvezu traganja za novim mogućnostima i modelima evangelizacije vjernika i društvene sredine. U skladu s tim, odbor ŽPV-a za naviještanje ima zadaću trajno skrbiti o unaprjeđenju župne kateheze, pastorala braka i obitelji, mladih, kao i različitih »posebnih « skupina vjernika i društvenih ustanova na njezinu području; otkrivati i poticati karizme i službe unutar župne zajednice te pomagati župniku u okupljanju i trajnoj formaciji župnih suradnika. Sinodski dokumenti Druge biskupijske sinode đakovačke i srijemske poželjnim smatraju da se unutar odbora za naviještanje osnuju i posebni pododbori. ${ }^{23} \mathrm{U}$ organiziranju rada odbora za naviještanje potrebno je izabrati jednu odgovornu osobu, voditelja odbora i tajnika. ${ }^{24}$ Zadaća voditelja je pozivati članove na sjednice odbora, biti član župnog pastoralnog vijeća, izvještavati o radu odbora na redovitim sjednicama, osobno biti uključen u jedan od oblika pastoralnokatehetskog rada i djelovanja, pomagati župniku u praćenju rada i života svih članova odbora te kritički promišljati o prioritetima i poteškoćama, posebice formaciji novih članova. Članovi odbora za naviještanje trebaju biti svi katehete svake pojedine katehetske skupine djece: voditelji predkrsne kateheze za roditelje novokrštenika, katehete djece predškolske dobi, djece osnovnoškolske dobi, srednjoškolske dobi, katehete mladih, posebice svi mladi koji su prošli formaciju »mladi za mlade«, katehete djece koja se pripremaju za sakramente prve pričesti i krizme, katehete voditelji interesnih skupina djece i mladih. Odbor trebaju činiti svi vjeroučitelji koji stanuju na području župe, svi katehete koji su završili Školu za župne suradnike, katehete voditelji katehetskih skupina za odrasle, primjerice

osječkoj nadbiskupiji, u: Vjesnik đakovačko-osječke nadbiskupije i Srijemske biskupije, 2011, 139, 1-2, str. 113-114.

23 Usp. Marin Srakić (proglasio), Izjave i odluke..., 131, str. 81-82. Primjerice pododbor za župnu katehezu, pododbor za brak i obitelj.

24 Tajnik vodi zapisnike susreta odbora za naviještanje i dostavlja svim članovima odbora. 
voditelji župnih obiteljskih skupina, katehete župne biblijske skupine, katehete roditelja prvopričesnika i krizmanika, ${ }^{25}$ vjeroučitelji »zaduženi« za pastoral škole i komunikaciju škole i župe, voditelji susreta bračnih parova različite dobi bračno-obiteljskog života, osobe zadužene za uređivanje župnog informativnog ili pastoralnog lista, mrežne stranice i društvene grupe.

\subsection{Narav i struktura odbora župnog pastoralnog vijeća za liturgiju}

Narav odbora župnog pastoralnog vijeća za liturgiju trebala bi se očitovati najprije kroz brigu za sadržajno, kvalitetno, pripremljeno i dostojanstveno slavlje dana Gospodnjega, primjerenu skrb o pripremi bogoslužnih i molitvenih slavlja u župi, promicanje različitih liturgijskih službi i aktivno sudjelovanje svih vjernika u liturgiji, skrb o doličnosti i urednosti paramenata, liturgijskog posuđa i knjiga te o uređenju liturgijskog prostora u skladu s liturgijskim propisima. ${ }^{26} \mathrm{U}$ odboru ŽPV-a za liturgiju, uz voditelja i tajnika odbora, po naravi službe trebaju biti: kateheta liturgijske interesne skupine; koordinator i voditelj čitača, izvanredni djelitelji svete pričesti; koordinator poslužitelja kod oltara ili ministranata, kateheta ministrantske skupine, zborovođe, orguljaši, predvoditelji pučkog pjevanja, sakristani, zvonari, urednik nedjeljnog liturgijskog listića s čitanjima i pjesmama, koordinator osoba koje uređuju liturgijski prostor i ruho, koordinator skupljača milostinje, koordinator redara na euharistijskim slavljima.

\subsection{Narav i struktura odbora župnog pastoralnog vijeća za karitativnu djelatnost}

Za Crkvu ljubav prema siromašnima nije neka vrst društvenog dobročinstva koje može mirne savjesti prepustiti i drugima, nego je to dio njezine najdublje naravi i nužni izraz same njene biti, posebice shvaćeno kao sastavni dio evangelizacijske zadaće. ${ }^{27}$ Članovi odbora župnog pastoralnog vijeća za karitativnu djelatnost pozvani su pratiti socijalne i društvene prilike stanovnika na teritoriju župe, promicati svijest solidarnosti i ljubavi za potrebite, te poticati i organizirati, osmišljavati, u suradnji sa župnim Caritasom i vjerničkim društvima, konkretne djelatnosti kršćanske dobrotvornosti unutar župne zajednice, udrugama civilnog društva, crkvenim i civilnim socijalnim ustanovama. Zatim, materijalno i duhovno pomagati župnomu Caritasu u brizi za socijalno najugroženije obitelji i pojedince u vlastitoj župnoj zajednici; u suradnji s dekanatskim, regionalnim i biskupijskim Caritasom brinuti se za permanentnu duhovnu formaciju članova župnog Caritasa; zajedno sa župnim Caritasom predlagati i osmišljavati sadržaje koji bi senzibilizirali cjelokupnu župnu zajednicu za potrebite, a posebice pratiti

25 Sinodski dokumenti Druge biskupijske sinode đakovačke i srijemske nalažu da se uz redovitu župnu katehezu za prvopričesnike i krizmanike redovito organiziraju susreti roditelja prvopričesnika i krizmanika i to dva puta godišnje u svakoj pripravnoj godini, u grupama od četiri do šest roditelja - bračnih parova. Usp. Isto, br. 389, str. 190-191; br. 432, str. 211.

26 Usp. Marin Srakić (odobrio) Pravilnik župnog pastoralnog..., u: Vjesnik Đakovačko-osječke nadbiskupije i Srijemske biskupije, 2011, 139, 1-2, str. 114.

27 Usp. Benedikt XVI, Deus caritas est..., 25, str. 39-40. 
stanje sve većeg broja nezaposlenih, prezaduženih, te uz župni Caritas učiniti sve kako se nitko u župnoj zajednici ne bi osjećao napuštenim. ${ }^{28} \mathrm{U}$ organiziranju rada odbora za karitativnu djelatnost potrebno je prema veličini župne zajednice animirati određen broj vjernika za planiranje, organiziranje, vrednovanje i ostvarivanje karitativnog djelovanja na području župe. ${ }^{29} \mathrm{Uz}$ voditelja i tajnika, članovi odbora pozvani su poticati župni Caritas na kvalitetniju suradnju s dekanatskim, regionalnim i biskupijskim Caritasom, poticati osnivanja vjerničkih društava i udruga karitativnog karaktera, razmatrati, osmišljavati i poticati kvalitetniji župni pastoral starijih osoba i bolesnika te članova njihovih obitelji, poticati župni Caritas na izradu župne karitativne kartoteke, promicati i osobno svjedočiti volonterski duh u župnoj zajednici i društvu, poticati i pomagati župnomu Caritasu u organiziranju trajnih mjesečnih prikupljanja i dostavljanja hrane i higijenskih potrepština. Odbor ŽPV-a za karitativnu djelatnost isto tako treba brinuti za socijalna pitanja koja se orijentiraju prema svim suvremenim socijalnim problemima koje crkveno učiteljstvo u posljednje vrijeme ističe: respektiranje života u svim stadijima, socijalna pravda, ljudska prava.

\subsection{Narav i struktura odbora župnog pastoralnog vijeća za izgradnju zajedništva}

Izgradnja kršćanskog zajedništva posebna je obveza svih članova Crkve. ${ }^{30}$ Odbor župnog pastoralnog vijeća za izgradnju zajedništva ima ponajprije trajnu zadaću poticati na izgradnju duhovne dimenzije zajedništva i izgradnju dijaloga ${ }^{31}$ na razini cjelokupnog župnog pastoralnog vijeća, raditi na kvaliteti »eklezijalnog zajedništva «32 te biti »most« odbora ŽPV-a za naviještanje, liturgiju i karitativnu djelatnost, njihovu međusobnu evangelizacijsko-pastoralno-katehetsku povezanost i usklađenost, posebice razvijati cjelokupno kršćansko tkivo župne zajednice, kao zajednice malih zajednica, ${ }^{33}$ biti poveznica među članovima župne zajednice, župe kao cjeline, poveznica župe i dekanata, župe i biskupije te župe i društvenih institucija. Nadalje, članovi odbora pozvani su vrednovati postojeće i tragati za novim oblicima kršćanskog zajedništva, stvarati što prikladnije modele strukturiranja zajedništva svih župnih struktura. U organiziranju rada odbora potrebno je stoga, prema veličini župne zajednice, animirati određen broj vjernika za izgradnju i ostvarivanje zajedništva. Uz voditelja ${ }^{34}$ i tajnika, članovi odbora župnog pastoralnog vijeća za izgradnju zajedništva ${ }^{35}$ dužni su, nadalje, njegovati,

28 Usp. Marin Srakić (proglasio), Izjave i odluke ..., 207, str. 118-119.

29 Uz voditelja i tajnika korisno je uključiti od deset do dvanaest osoba.

30 Usp. Eugen Pusić, Uvjeti institucionalne stabilizacije, u: Hrvatska kao socijalna država, Zagreb, 1997, str. 9.

31 Usp. Živan Bezić, Isto, 36.

32 Marin Srakić (proglasio), Izjave i odluke..., 554, str. 258.

33 Usp. Isto, 554, str. 258.

34 Dužnosti i nadležnosti voditelja i tajnika odbora istovjetne su i kod voditelja odbora župnog pastoralnog vijeća za naviještanje, liturgiju i karitativnu djelatnost.

35 Budući da je riječ o najzahtjevnijem području, poželjno je da voditelj i članovi odbora ŽPV-a za izgradnju zajedništva imaju neku filozofsko-teološku naobrazbu. 
razvijati i povezivati »kategorijalni « pastoralni pristup i rad, razvijati na području župe međureligijski i međukonfesionalni dijalog, povezivati vjerničke udruge, društva i pokrete unutar župne zajednice, jačati njihov misionarski duh te promicati klimu radosti, suodgovornosti i zajedništva.

\section{Analiza stanja-kritički osvrt župnih pastoralnih vijeća i odbora župnih pastoralnih vijeća za naviještanje, liturgiju i karitativnu djelatnost u Đakovačko-osječkoj nadbiskupiji}

Analiza $^{36}$ je provedena na temelju službenih zapisa s dekanatskih susreta članova župnih pastoralnih vijeća i pojedinih odbora održanih u posljednjih pet godina. Susreti su održani u šesnaest dekanata Đakovačko-osječke nadbiskupije. Riječ je o susretima koje je na tragu sinodalne suodgovorne formacije, edukacije i skrbi organizirao Pastoralni centar Đakovačko-osječke nadbiskupije. ${ }^{37} \mathrm{U}$ razdoblju od 2011. do 2015. održana su četiri susreta: prve, druge, četvrte i pete godine mandata sadašnjeg saziva župnih pastoralnih vijeća. ${ }^{38}$ Prvi susret organiziran je za sve članove župnog pastoralnog vijeća, a ostali za članove odbora ŽPV-a za naviještanje, liturgiju i karitativnu djelatnost. ${ }^{39}$ Analiza pokazuje koju mjeru sinodalnosti i crkvene odgovornosti župa, župna pastoralna vijeća i vijećnici očituju, jesu li župe (župnici i župljani) ustanovile vijeća i strukturirali i organizirali ih po odborima, ${ }^{40}$ ogleda li se i u kojoj mjeri među članovima ŽPV-a i odborima ŽPV-a cjelokupna slika i evangelizacijsko-pastoralno-katehetsko stanje župne zajednice, koliko su u ŽPV birani župljani koji se odlikuju aktivnim sudjelovanjem u životu župe ili su samo puki promatrači i potvrditelji onoga što im pastir i predvoditelj zajednice sugerira i predloži?

\section{1. Članovi župnih pastoralnih vijeća prema dobi i spolu}

Kriterij sinodalnosti podrazumijeva ravnopravnu zastupljenost župljana svih životnih dobi, socijalnih i obrazovnih kategorija, zajednica, zaseoka ili četvrti, različitih društveno-kulturnih stanja i područja, zvanja i apostolata. Pastoralno je djelovanje na taj način cjelovitije, suodgovornije i sveobuhvatnije. Kriterij crkvenosti odnosi se na odlikovanje vijećnika uzornim kršćanskim životom, razboritošću, aktivnim sudjelovanjem u životu župne zajednice te spremnošću na promišljanje o pastoralnim pitanjima u crkvenom duhu.

36 Statističke podatke obradio je mr. sc. Igor Jakobfi, tajnik Ureda za Socijalni nauk Đakovačkoosječke nadbiskupije.

37 Usp. Marin Srakić (proglasio), Izjave i odluke..., 574, str. 265.

38 Posljednji izbori bili su u veljači 2011. godine, a mandat prema Pravilniku traje pet godina.

39 Na susrete su pozivani članovi odbora i svećenici-župnici, a u župama u kojima odbori nisu strukturirani svi članovi ŽPV-a.

40 Usp. Marin Srakić (odobrio), Pravilnik..., čl. 2. 
Tablica 1. Članovi župnih pastoralnih vijeća prema dobi i spolu

\begin{tabular}{|c|c|c|c|c|c|c|c|}
\hline & \multicolumn{6}{|l|}{ Dob } & \multirow[b]{2}{*}{ nepoznata } \\
\hline & $<21$ & $21-30$ & $31-40$ & $41-50$ & $51-65$ & $>65$ & \\
\hline Ukupno & $\begin{array}{l}13 \\
(0,6 \%)\end{array}$ & $\begin{array}{l}132 \\
(6,3 \%)\end{array}$ & $\begin{array}{l}302 \\
(14,4 \%)\end{array}$ & $\begin{array}{l}592 \\
(28,3 \%)\end{array}$ & $\begin{array}{l}688 \\
(32,9 \%)\end{array}$ & $\begin{array}{l}156 \\
(7,4 \%)\end{array}$ & $\begin{array}{l}202 \\
(9,6 \%)\end{array}$ \\
\hline Muški & $\begin{array}{l}5 \\
(0,2 \%)\end{array}$ & $\begin{array}{l}54 \\
(2,5 \%)\end{array}$ & $\begin{array}{l}126 \\
(6,0 \%)\end{array}$ & $\begin{array}{l}176 \\
(8,4 \%)\end{array}$ & $\begin{array}{l}261 \\
(12,5 \%)\end{array}$ & $\begin{array}{l}74 \\
(3,5 \%)\end{array}$ & $\begin{array}{l}77 \\
(3,6 \%)\end{array}$ \\
\hline Ženski & $\begin{array}{l}8 \\
(0,3 \%)\end{array}$ & $\begin{array}{l}78 \\
(3,7 \%)\end{array}$ & $\begin{array}{l}176 \\
(8,4 \%)\end{array}$ & $\begin{array}{l}416 \\
(19,9 \%)\end{array}$ & $\begin{array}{l}427 \\
(20,4 \%)\end{array}$ & $\begin{array}{l}82 \\
(3,9 \%)\end{array}$ & $\begin{array}{l}125 \\
(5,9 \%)\end{array}$ \\
\hline
\end{tabular}

Od ukupnog broja vijećnika ŽPV-a (2.085), ${ }^{41}$ većina pripada dobnim skupinama između četrdeset i prve i šezdeset i pete godine života, ili $61,3 \%$. Od četrdeset i prve do pedesete godine života $28,3 \%$, a 32,9 \% od pedeset i prve do šezdeset i pete godine života. Budući da se članom ŽPV-a može postati punoljetnošću, ${ }^{42}$ do 21 godine života članova ŽPV-a je $0,6 \%$, a 6,3\% je članova ŽPV-a od dvadeset i prve do tridesete godine. Kada se podatci raspodijele prema broju župa, uočavamo da je u sto četrdeset i četiri ŽPV-a — njih 94,1 \%, dob vijećnika između 51 do 65 godina. Znakovit je podatak da 60,7\%, ili devedeset i tri ŽPV-a, nema vijećnika mlađeg od 30 godina, a 93,5\%, odnosno sto četrdeset i tri ŽPV-a, niti jednog mlađeg vijećnika od 21 godine života. Za mjesnu Crkvu zabrinjavajući je podatak da u četrdeset i osam župa, odnosno za 202 vijećnika, 125 žena i 77 muškaraca članova ŽPV-a, župnici nisu naveli godinu rođenja, formularom predviđen podatak. ${ }^{43}$

\section{2. Članovi župnih pastoralnih vijeća prema zvanju i zanimanju}

Tablica 2. Članovi župnih pastoralnih vijeća prema područjima zanimanja

\begin{tabular}{|l|l|}
\hline Područja zanimanja i zvanja & Članovi ŽPV-a \\
\hline Domaćinstvo & $231(11,0 \%)$ \\
\hline Ekonomija & $122(5,8 \%)$ \\
\hline Kultura & $9(0,4 \%)$ \\
\hline Medicina & $90(4,3 \%)$ \\
\hline Obrazovanje & $329(15,7 \%)$ \\
\hline
\end{tabular}

41 Podatci o zastupljenosti dobnih skupina ukazuju na strukturalnu neujednačenost župnih pastoralnih vijeća.

42 Usp. Marin Srakić (odobrio), Pravilnik ...3, str. 2.

43 Podatak se može shvatiti kao župnikovo nepoznavanje članova ŽPV-a i kao njegova nezainteresiranost za tako važnu župnu sinodalnu strukturu. 


\begin{tabular}{|l|l|}
\hline Policija/vojska & $38(1,8 \%)$ \\
\hline Poljoprivreda & $67(3,2 \%)$ \\
\hline Pravo & $30(1,4 \%)$ \\
\hline Tehnika & $200(9,5 \%)$ \\
\hline Školovanje & $70(3,3 \%)$ \\
\hline Mirovina & $250(11,9 \%)$ \\
\hline Ostalo ${ }^{44}$ & $494(23,6 \%)$ \\
\hline Nepoznato & $155(7,4 \%)$ \\
\hline Ukupno & $2085(100 \%)$ \\
\hline
\end{tabular}

Tablica 3. Broj župa poznatog/nepoznatog zanimanja prema vrsti župe

\begin{tabular}{|l|l|l|l|}
\hline & Poznato zanimanje & Nepoznato zanimanje & Ukupno \\
\hline Gradska & $30(73,1 \%)$ & $11(23,8 \%)$ & $41(100 \%)$ \\
\hline Seoska & $80(71,4 \%)$ & $32(28,5 \%)$ & $112(100 \%)$ \\
\hline
\end{tabular}

Analiza zanimanja vijećnika župnih pastoralnih vijeća pokazuje kako je najviše vijećnika zaposleno na području različitih uslužnih i administrativnih djelatnosti (23,6 \%), zatim u obrazovanju (15,7\%), vođenju domaćinstva (11,0 $\%)$ te u različitim strojarskim i graditeljsko-tehničkim zanimanjima $(9,5 \%)$, a u mirovini je $11,9 \%$. S druge strane, najmanje zastupljena zanimanja povezana s policijom i vojskom $(1,8 \%)$, pravom $(1,4 \%)$ i kulturom $(0,4 \%)$. Za 7,4 \% vijećnika nije navedeno zanimanje. Nejasno je kako i na koji način župnik može računati sa znanjima i vještinama određenog vijećnika ako mu je nepoznato koje je njegovo profesionalno zanimanje. Razlika u nepoznavanju zanimanja između gradskih i seoskih župa nije značajna, podjednako je nepoznato i gradskim i seoskim župnicima. Od ukupnog broja vijećnika u gradu nepoznatog je zanimanja njih $6,6 \%$ - taj se udio odnosi na 11 župa ili $23,8 \%$. Slični su podatci i za seoske župe: od njihova ukupnog broja vijećnika, 7,8\% je nepoznatog zanimanja udio se odnosi na 32 župe, odnosno $28,5 \%$.

\section{3. Župe i broj ustanovljenih odbora $\check{Z} P V-a$ za naviještanje, liturgiju $i$ karitativnu djelatnost}

Tablica 4. Župe i strukturirani, organizirani te ustanovljeni odbori župnoga pastoralnog vijeća

\begin{tabular}{|l|l|l|l|l|}
\hline $\begin{array}{l}\text { Nema ni jedan } \\
\text { odbor ŽPV-a }\end{array}$ & Ima odbor & $\begin{array}{l}\text { Jedan odbor } \\
\text { ŽPV-a }\end{array}$ & $\begin{array}{l}\text { Dva odbora } \\
\text { ŽPV-a }\end{array}$ & $\begin{array}{l}\text { Tri odbora } \\
\text { ŽPV-a }\end{array}$ \\
\hline $65(42,4 \%)$ & $88(57,5 \%)$ & $42(27,4 \%)$ & $31(20,2 \%)$ & $15(9,8 \%)$ \\
\hline
\end{tabular}

44 »Ostalo« se odnosi na različita administrativna službenička, uslužna i trgovačka zanimanja. Usp. Državni zavod za statistiku, Nacionalna klasifikacija zanimanja, u: Narodne novine, 2010, str.147. 
Tablica 5. Broj Odbora ŽPV-a ustanovljenih prema vrsti župe (gradska/seoska) ${ }^{45}$

\begin{tabular}{|l|l|l|l|l|}
\hline Vrsta župe & \multicolumn{2}{|l|}{ Ima odbor/odbore } & \multirow{2}{*}{ Nema niti jedan } \\
\hline \multirow{3}{*}{ Gradska } & \multirow{3}{*}{$31(75,6 \%)$} & Jedan odbor & $11(26,8 \%)$ & \multirow{2}{*}{$10(24,3 \%)$} \\
\cline { 3 - 4 } & & Dva odbora & $11(26,8 \%)$ & \\
\cline { 3 - 4 } & & Tri odbora & $9(21,9 \%)$ & \\
\hline \multirow{3}{*}{ Seoska } & \multirow{2}{*}{$57(50,8 \%)$} & Jedan odbor & $31(27,6 \%)$ & \multirow{2}{*}{$55(49,1 \%)$} \\
\cline { 3 - 4 } & & Dva odbora & $20(17,8 \%)$ & \\
\cline { 3 - 4 } & & Tri odbora & $6(5,3 \%)$ & \\
\hline
\end{tabular}

Odlukom biskupa Ćirila Kosa od 15. svibnja 1988., sve župe pozvane su osnovati župna pastoralna vijeća na području Đakovačke i Srijemske biskupije, danas Đakovačko-osječke nadbiskupije. ${ }^{46}$ Dvadeset i sedam godina od donošenja te odluke biskupa Ćirila Kosa, od ukupno 153 župe, u četiri župe Đakovačkoosječke nadbiskupije ne postoji župno pastoralno vijeće. Prema Pravilniku župnog pastoralnog vijeća iz 2011. u Đakovačko-osječkoj nadbiskupiji župna pastoralna vijeća strukturirana su i organizirana u tri odbora: odbor ŽPV-a za naviještanje, odbor ŽPV-a za liturgiju i odbor ŽPV-a za karitativnu djelatnost. ${ }^{47}$ Od ukupnog broja vijeća u Nadbiskupiji (149), petnaest župa osnovalo je Pravilnikom predviđena sva tri odbora ŽPV-a, a sedamdeset i tri župe jedan ili dva odbora. Činjenica da je 9,8 \% župa ustanovilo sva tri zadana odbora ŽPV-a, dok 42,4 \% župa nema ni jedan odbor ŽPV-a, ukazuje na ozbiljnu »slabost « sinodalne svijesti i suodgovornosti, posebice nedostatak sinodalnosti župnika i župnih zajednica. ${ }^{48}$ Nadalje, ukazuje i na nedovoljnu svijest sveopćeg svećeništva, svih vjernika i vijećnika ŽPV-a. Ono se posebno odnosi na seoske župe. Naime, polovica seoskih župa (51\%) ustanovilo je odbore ŽPV-a. Jedan odbor je ustanovilo 27,6\% seoskih župa, dva odbora 17,8 \%, a 5,3\% tri odbora. U gradovima je 26,8 \% župa osnovalo jedan i dva odbora ŽPV-a, a tri odbora ŽPV-a 21,9 \% župa. Premda je za sve »iskorake« potrebno vrijeme, župe, župne zajednice i župnici »samo djelomičnim« osnivanjem odbora ŽPV-a očituju i ozbiljne propuste i nedostatke u razumijevanju kako evangelizacijsko-pastoralno-katehetskog procesa, rada i nastojanja, tako i cjelovitog i sustavnog strukturiranja, organiziranja, posebice

45 Od ukupnog broja župa 18 ih je u naselju manjem od 500 stanovnika, 36 u naselju od 501 do 1000 stanovnika, 28 u naselju od 1001 do 2000 stanovnika, 24 u naselju od 2001 do 5000 stanovnika, 11 u naselju od 5001 do 10000 stanovnika, 4 u naselju od 10001 do 20000, 10 u naselju od 20001 do 50000 i 21 u naselju od 50001 do 100000 stanovnika.

46 Odluka biskupa Ćirila Kosa od 15. svibnja 1988., br. 981/1988. Odluku je nakon osamostaljenja Republike Hrvatske potvrdio biskup Marin Srakić okružnicom od 4. lipnja 1997., br. 1100/1997.

47 Usp. Marin Srakić (odobrio), Pravilnik..., 10, str. 2.

48 Usp. Marin Srakić (proglasio), Izjave i odluke..., 2-13, str. 20-27. 
planiranja te ostvarenja pastoralnih smjernica mjesne Crkve, ${ }^{49}$ napose sinodskih dokumenta Druge biskupijske sinode đakovačke i srijemske. Dimenzije i dosezi postojećeg pastoralnog djelovanja vrlo dobro ilustriraju podatci o broju župa koje su ustanovile pojedini odbor, odnosno broj vijeća kojima nedostaje neki od odbora. U 64,1 \% župa ne postoji odbor za naviještanje, 68 \% župa nema odbor koji ce trajno, konkretno i kompetentno planirati, provoditi, vrednovati i promicati liturgijski život. Isto tako 70,6 \% župa nema odbor ŽPV-a za karitativnu djelatnost. Analiza ukazuje na to kako se na području ŽPV-a ne ostvaruje cjelovito pastoralno-katehetsko djelovanje u više od stotinu župa Đakovačko-osječke nadbiskupije. Poteškoća nije samo u tome što župi nedostaje jedno sinodalno tijelo koje bi na sustavan i organiziran način planiralo, provodilo i vrednovalo pastoralno djelovanje, nego što će posljedično negativno djelovati na evangelizacijsko-pastoralno-katehetski rad u cjelini. Važno polazište za buduće izbore župnih pastoralnih vijeća na dekanatskoj razini ukazuju podatci o broju župa koje su osnovale sve ili samo neke od odbora ŽPV-a. Za pretpostaviti je da pastoralni prioriteti i projekti župa na razini jednog dekanata »ostavljaju traga« ili imaju utjecaj na »okolne« župne zajednice istog dekanata, njihova župna pastoralna vijeća i samu strukturu. Stoga, ukoliko se želi »unaprijediti, osnažiti i poboljšati« pastoralna praksa u svim dekanatima i župnim zajednicama, potrebna je ne samo »snažnija « edukacija i formacija vjernika laika, nego i »izabiranje i određivanje jedne župe kao pilot projekta « koja će u dekanatu ostvarivati sinodske smjernice, i na taj način postupno širiti duh sinodalnosti, suodgovornosti, strukturiranosti i organiziranosti, napose ujednačenosti pastoralne prakse.

\section{4. Članovi Župnih pastoralnih vijeća uključenih u odbore ŽPV-a za naviještanje, liturgiju i karitativnu djelatnost prema spolu i angažiranosti}

Tablica 6. Članovi Župnih pastoralnih vijeća uključenih u odbore ŽPV-a za naviještanje, liturgiju i karitativnu djelatnost prema spolu

\begin{tabular}{|l|l|l|l|l|}
\hline Spol & \multicolumn{2}{|l|}{ Član odbora } & \multirow{2}{*}{ Nije član odbora } \\
\hline \multirow{3}{*}{ Muški } & \multirow{3}{*}{$150(19,4 \%)$} & Naviještanje & $58(7,5 \%)$ & \multirow{3}{*}{$623(80,5 \%)$} \\
\cline { 3 - 4 } & & Liturgija & $55(7,1 \%)$ & \\
\cline { 3 - 4 } & & Karitas & $37(4,7 \%)$ & \\
\hline \multirow{3}{*}{ Ženski } & \multirow{3}{*}{$336(25,6 \%)$} & Naviještanje & $153(11,6 \%)$ & \multirow{3}{*}{$976(74,3 \%)$} \\
\cline { 3 - 4 } & & Liturgija & $115(8,7 \%)$ & \\
\cline { 3 - 4 } & & Karitas & $68(5,1 \%)$ & \multirow{2}{*}{$1599(76,6 \%)$} \\
\hline Ukupno & $486(23,3 \%)$ & & \\
\hline
\end{tabular}

49 Usp. Nikola Vranješ, Župno pastoralno vijeće u dinamici teološko-pastoralnog programiranja, u: Riječki teološki časopis, 2009, 17, 1, str. 169-196. 
Tablica 7. Vijećnici ŽPV-a koji su angažirani u dva ili tri odbora ŽPV-a

\begin{tabular}{|l|l|l|l|l|l|}
\hline \multicolumn{2}{|l|}{ Angažirani u dva odbora } & \multicolumn{3}{l|}{ Angažirani u tri odbora } \\
\hline Žensko & Muško & Ukupno & Žensko & Muško & Ukupno \\
\hline $44(66,6 \%)$ & $22(33,3 \%)$ & $66(100 \%)$ & $4(50,0 \%)$ & $4(50,0 \%)$ & $8(100 \%)$ \\
\hline $\begin{array}{l}\text { Aktivan u } \\
\text { župi }\end{array}$ & $\begin{array}{l}\text { Nije aktivan } \\
\text { u župi }\end{array}$ & Ukupno & $\begin{array}{l}\text { Aktivan u } \\
\text { župi }\end{array}$ & $\begin{array}{l}\text { Nije aktivan } \\
\text { ǔupi }\end{array}$ & Ukupno \\
\hline $50(75,7 \%)$ & $16(24,2 \%)$ & $66(100 \%)$ & $7(87,5 \%)$ & $1(12,5 \%)$ & $8(100 \%)$ \\
\hline
\end{tabular}

Na području Đakovačko-osječke nadbiskupije unutar 149 župnih pastoralnih vijeća uključeno je 2.085 vijećnika, od kojih je u nekom od odbora njih 486, odnosno $23,3 \%$. Žena je u župnim pastoralnim vijećima skoro dvostruko više $(62,9 \%)$, a muškaraca $37,0 \%$. No, znakovito je da u odborima ŽPV-a udio žena u odnosu na ukupan broj žena u ŽPV-ima nije dvostruko veći. U odboru ŽPV-a za naviještanje muškaraca je 7,5 \%, žena je $11,1 \%$ u odnosu prema ukupnomu broju muškaraca i žena u ŽPV-ima, slični su rezultati i za druga dva odbora: u odboru ŽPV-a za liturgiju muškaraca je 7,1 \%, a žena 8,7 \%, dok je u odboru ŽPV-a za karitativnu djelatnost muškaraca 4,7 \%, a žena 5,1 \%. ${ }^{50}$ Kako bi uočili razloge i stekli objektivniji uvid zašto je dvostruko manje vijećnika muškaraca u ŽPV-ima, trebalo bi proučiti kandidacijske liste pastoralnih vijeća. Od ukupnog broja vijećnika ŽPV-a, njih 3,5\%, ili 74 vijećnika, angažirano je u dva ili tri odbora. Šezdeset i šest vijećnika ŽPV-a angažirano je u dva odbora ŽPV-a, a osam vijećnika u tri odbora ŽPV-a. Kada se ti podatci raspodijele prema broju ŽPV-a, uočavamo da od ukupnog broja ŽPV-a koji imaju barem jedan od odbora, 37,5 \% njih ima barem jednog vijećnika koji je angažiran u dva ili tri odbora. Podatci za gradske i seoske župe su podjednaki. Razlike su uočljive u raspodjeli prema spolu: dvostruko je više žena: njih četrdeset i četiri angažirane su u dva odbora ŽPV-a, a dvadeset i dva vijećnika angažirani su u dva odbora ŽPV-a. Podatci s jedne strane ukazuju na spremnost jednog malog dijela vjernika angažirati

50 Znakovita je daleko veća ukupna zastupljenost žena. Naime, slobodno možemo postaviti pitanje nije li manjak muškaraca u vijećima odraz dubljeg problema koji se odnosi na koncepciju samog dosadašnjeg pastorala, koji je premalo u obzir uzimao antropološku činjenicu da su muškarci i žene različiti, da ih pokreću različiti motivi i da posljedično tomu imaju i različite interese u skladu s kojima im je i potrebno oblikovati i različiti pastoralni pristup. Usp. http://www.dzs.hr 8. listopada 2015.; Alan S. Miller-John P. Hpffmann, RiskandReligion: An Explanation of Gender Differences in Religiosity, u: Journal for theScientificStudyofReligion, 1995, 34, 1, str. 63-75.; Antonio Dragun, Povezanost religiozne orijentacije, seksualnosti i prosocijalnosti, u: Društvena istraživanja, 2003, 12, 1-2, str. 201-223. 
se, no s druge strane, kako je Crkva đakovačko-osječka »malo stado« u kojem manjina praktičnih zrelih, izgrađenih i odgovornih vijećnika ŽPV-a i vjernika djelomično nadomješta manjak svijesti sinodalnosti i crkvenosti većine.

\section{5. Članovi odbora župnih pastoralnih vijeća za naviještanje, liturgiju $i$ karitativnu djelatnost prema dobi i spolu}

Tablica 8. Članovi odbora ŽPV-a za naviještanje, liturgiju i karitativnu djelatnost prema dobi i spolu

\begin{tabular}{|c|c|c|c|c|c|c|c|c|}
\hline \multirow{2}{*}{ Spol } & \multirow{2}{*}{ Odbor } & \multicolumn{6}{|l|}{ Dob } & \multirow[b]{2}{*}{ Nepoznato } \\
\hline & & $<21$ & $21-30$ & $31-40$ & $41-50$ & $51-65$ & $>65$ & \\
\hline \multirow{3}{*}{ 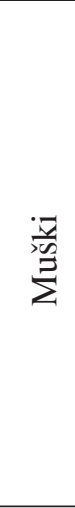 } & 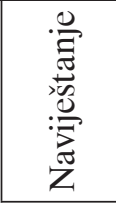 & $0 \%$ & $\begin{array}{l}15,5 \\
\%\end{array}$ & $17,2 \%$ & $24,1 \%$ & $22,4 \%$ & $5,1 \%$ & $15,5 \%$ \\
\hline & 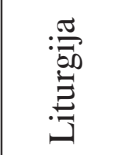 & $0 \%$ & $7,2 \%$ & $14,5 \%$ & $29,0 \%$ & $29,0 \%$ & $7,2 \%$ & $12,7 \%$ \\
\hline & 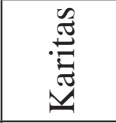 & $0 \%$ & $5,4 \%$ & $10,8 \%$ & $35,1 \%$ & $37,8 \%$ & $10,8 \%$ & $0 \%$ \\
\hline \multirow{3}{*}{$\begin{array}{l}\frac{\vec{*}}{\mathscr{N}} \\
\stackrel{0}{\mathbb{N}}\end{array}$} & 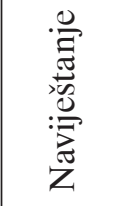 & $0,6 \%$ & $8,4 \%$ & $20,2 \%$ & $32,0 \%$ & $26,1 \%$ & $2,6 \%$ & $9,8 \%$ \\
\hline & 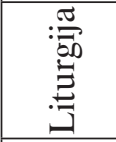 & $0,8 \%$ & $4,3 \%$ & $16,5 \%$ & $30,4 \%$ & $34,7 \%$ & $6,0 \%$ & $6,9 \%$ \\
\hline & 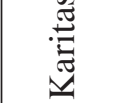 & $0 \%$ & $0 \%$ & $4,4 \%$ & $32,3 \%$ & $44,1 \%$ & $11,7 \%$ & $7,3 \%$ \\
\hline
\end{tabular}

Za izbor članova odbora ŽPV-a važna je spremnost angažirati se, ali i dob. Naime, u pojedinim seoskim župama, za razliku od gradskih, teže je ostvariti pastoralne smjernice, s obzirom na strukturu ŽPV-a i Pravilnikom predviđenih odbora. Za jedan odbor ŽPV-a u nekom idealiziranom obliku trebalo bi pronaći od 6 do 20 zrelih vjernika ${ }^{51}$ iz više različitih dobnih, spolnih, obrazovnih i drugih

51 Usp. Pero Aračić, Gordan Črpić, Zvonko Pažin, Karlo Višaticki, Ivo Đžinić, Kršćanski identitet i obitelj, u: Vjesnik Đakovačko-osječke nadbiskupije i Srijemske biskupije, 2011, 6, str. 585.; Karl Rahner, SchriftenzurTheologie, Zürich — Einsiedeln — Köln, 1971, str. 22. 
skupina. Od ukupnog broja muškaraca, u sva tri odbora ŽPV-a udio muškaraca mlađih od 40 godina života ne prelazi 17,2 \%, a u odborima ŽPV-a za liturgiju i karitativnu djelatnost nema ni jednog muškaraca do dvadeset i prve godine života. U odboru ŽPV-a za naviještanje 22,4 \% muškaraca je između četrdeset i prve i šezdeset i pete godine starosti, a u odboru ŽPV-a za liturgiju 37,8\% muškaraca je između pedeset i prve i šezdeset i pete godine. Od ukupnog broja žena u bilo kojem od odbora ŽPV-a udio žena mlađih od četrdeset godina ne prelazi više od 20,2 \%. Žena između četrdeset i prve i šezdeset i pete godine starosti je 26,1 \% u odborima ŽPV-a za naviještanje i do 44,1 \% u odborima ŽPV-a za karitativnu djelatnost. Razvidno je da su nam ŽPV-i i odbori ŽPV-a »stari«. Postoje različiti čimbenici zašto je to tako, od toga da je Hrvatska demografski gledano u stanju duboke starosti52 ${ }^{52}$ a do toga da su mladi u određenoj mjeri distancirani od Crkve, te manje angažirani i uključeni u njezino pastoralno-katehetsko djelovanje. ${ }^{53}$

\section{Pastoralne smjernice za rad $\check{Z} P V-a$ i odbora $\check{Z} P V-a$ za naviještanje, liturgiju i karitativnu djelatnost}

Kako bi se »stvarao" duh sinodalnosti, crkvenosti, suodgovornosti te veće angažiranosti članova ŽPV-a i članova odbora ŽPV-a, posebice kvalitetnijega i cjelovitijeg pastoralno-katehetskog djelovanja na području Đakovačko-osječke nadbiskupije potrebno je neposredno pred izbore ŽPV-a, zbog pastoralne suodgovornosti ŽPV-a, podrobnije i preciznije odrediti kriterije prema kojima će se predložiti kandidate, kritički osvrnuti na odabir kandidata, predlagati kandidate na temelju kriterija crkvenosti. Potrebno je veću pozornost usmjeriti ka ravnomjernijoj zastupljenosti kandidata svih spolnih, dobnih, obrazovnih i profesionalnih kategorija. Nakon izbora ŽPV-a, s članovima cijeloga ŽPV-a potrebno je tražiti kvalitetne angažirane vjernike za angažman u odborima ŽPV-a za naviještanje, liturgiju i karitativnu djelatnost, te ih nakon ustanove odbora ŽPV-a uključivati u pojedini odbor. Angažirane vjernike potrebno je uključivati u odbore ŽPV-a na način da njihova profesionalna zanimanja, znanja i vještine bliske naravi pojedinog odbora ŽPV-a. Sve članove ŽPV-a uputno je uključiti u neki od odbora ŽPV-a. Na razini nadbiskupije, tijekom petogodišnjeg mandata, barem jednom treba organizirati »susret« svih članova ŽPV-a i članova odbora ŽPV-a u prvostolnici u Đakovu, s ciljem stvaranja povezanosti i zajedništva cijele mjesne Crkve. Na dekanatskoj razini, jednom godišnje bilo bi dobro ciljano približiti narav, svrhu, zadaće i rad članova odbora ŽPV-a, organizirati forma-

52 Usp. Ivo Nejašmić i Aleksandar Toskić, Starenje stanovništva u Hrvatskoj — sadašnje stanje i perspektive, u: Hrvatski geografski glasnik, 2013, 75, 1, str. 89-110.

53 Više o specifičnostima razumijevanja i doživljaja religioznog u mladenačkoj dobi vidi u: James Fowler, Stagesoffaith: Reflections on a Decade of Dialogue, u: Christian Educational Journal, 1992, 13, str. 1.; Ch. Smith - M. Denton - R. Faris, M. D. Regnerus, Mapping Adolescent, American Religious Participation, u: Journal for the Scientific Study of Religion, 2002, 41, str. 597-612. 
tivne susrete za članove ŽPV-a i članove odbora ŽPV-a. Na župnoj razini potrebno je izraditi petogodišnje planove i programe za članove ŽPV-a, najmanje četiri puta redovito sazivati susrete svih članova te, ovisno o zahtjevnosti i pastoralnim potrebama, izrađenim planovima i programima župne zajednice te naravi pojedinog odbora ŽPV-a, sazivati susrete članova odbora ŽPV-a za naviještanje, liturgiju i karitativnu djelatnost. Potrebno je detaljno razraditi pojedine operativne etape, podijeliti zaduženja te izraditi metodu i dinamiku evaluacije provedbe plana. U župnim zajednicama, ukoliko postoje pastoralne potrebe, treba ustanoviti i pododbore u odborima ŽPV-a. Zbog kvalitete rada bilo bi dobro da na početku pastoralno-katehetske godine voditelji odbora predstave analizu i vrednovanje prošlogodišnjeg rada svim članovima odbora ŽPV-a, a nakon toga i svim članovima ŽPV-a. Na temelju ostvarenog i neostvarenoga te zadanog jednogodišnjeg i petogodišnjeg plana potrebno je izraditi naputke za izradu prijedloga plana za sljedeću pastoralnu godinu. Redovito, mjesečno izvještavati župnu zajednicu o planovima, djelatnostima i dinamici ostvarenja i rada ŽPV-a i članova odbora ŽPV-a putem župnog informativnog/pastoralnog lista, oglasne ploče ili na mrežnim stranicama župe. Najmanje pola godine prije izbora za novi saziv župnih pastoralnih vijeća, treba sastaviti i istaknuti kandidacijske liste s relevantnim podatcima kandidata. Potrebno je razraditi i u dugoročni pastoralni plan župne zajednice ugraditi trajnu formaciju župljana za aktivno življenje vjerničke suodgovornosti, posebice kada se ostvare »okolnosti« za osnivanje četvrtog odbora ŽPV-a, odbora za izgradnju zajedništva, te na razini Nadbiskupije osnovati Povjerenstvo za župna pastoralna vijeća, koje će trajno pratiti i vrednovati strukturiranost i konkretno djelovanje ŽPV-a i odbora ŽPV-a za naviještanje, liturgiju i karitativnu djelatnost.

\section{Zaključak}

Navedene Pastoralne smjernice za rad župnih pastoralnih vijeća i članova odbora župnih pastoralnih vijeća za naviještanje, liturgiju i karitativnu djelatnost te učinjeni kritički osvrt i analiza pokazuju kako postoje ozbiljna ograničenja i poteškoće u strukturiranosti, ljudskom/vjerničkom potencijalu, a posljedično tomu i pastoralno-katehetskomu radu župnih pastoralnih vijeća i odbora ŽPV-a za naviještanje, liturgiju i karitativnu djelatnost na području Đakovačko-osječke nadbiskupije. Predložene će konkretne pastoralne smjernice moći biti ostvarene tek ukoliko njihovo planiranje i ostvarenje bude pratio prikladan ustroj i oblikovanje pastoralnih struktura i trajan katehetski rad s postojećim i budućim vijećnicima župnih pastoralnih vijeća, članovima odbora ŽPV-a i svim članovima župne zajednice. Stoga, prije izbora za vijećnike župnih pastoralnih vijeća, na razini svake župe, kao pastoralni prioritet, treba biti cjelovito informiranje i formiranje cijele župne zajednice o nužnosti, značaju, važnosti, ustroju, zadaćama i načinu rada pastoralnih vijeća i pripadajućih im odbora. Nužno je da u takav informativno-formativni program bude uključena cijela župna zajednica, svi njezini članovi, koji biraju i koji će biti birani. 
An Analysis and Critique of Parish Pastoral Councils and their Committees in the Đakovo-Osijek Archdiocese

Stanislav Šota*

Summary

In keeping with the spirit of synodality of the Second Vatican Council, the Archdiocese of Đakovo-Osijek strives to link all members of the local Church into a coresponsible whole whereby all the baptized may achieve self-realization within the scope of their particular charism by participating with co-responsibility in the life of the Church. Attainment of the synodal spirit in the local Church »must « especially be recognizable in the parochial structures, particularly in the Parish Pastoral Councils. The tasks of the Parish Pastoral Committee in the function of a consultative body are: to help the parish priest in determining evangelization-pastoral-catechetical priorities and needs in the field; deciding on priority tasks in the parish and seeking out and making the effort to include parishioners in commissions and committees foreseen in the Synodal Documents of the Đakovo-Srijem Diocese and the Handbook for Parish Pastoral Councils of the Đakovo-Osijek Archdiocese. Commissions of the Parish Pastoral Councils for Evangelization, the Liturgy and Charity Activities provide the necessary internal structuredness according to which goals of the Parish Pastoral Councils may be achieved. The latter and their boards ought to be organized in such a way that their nature, features and tasks structurally embody all respective stages of evangelization and so become the structural framework for planning, implementation and evaluation of the pastoral activity of the parish as a whole.

Key words: synodality, co-responsibility, structuredness, Parish Pastoral Council, Commission of the Parish Pastoral Council for Evangelization, the Liturgy and Charity Activities

* Stanislav Šota, Th.D., The Catholic Faculty of Theology in Đakovo, P. Preradovića 17, 34400 Đakovo, Croatia. E-mail: stanislav.sota@os.t-com.hr 